\title{
TYPES AND PREDICTORS OF INTERFERON/RIBAVIRIN INDUCED CARDIAC COMPLICATIONS IN THE EGYPTIAN PATIENTS WITH CHRONIC HEPATITIS C VIRUS
}

\author{
Ibtesam I El-Dosouky, M.D.*, Soha A ElHawari, M.D.**, Mohamed H Emara, M.D.**, Emad F \\ Hamed, M.D.**** \\ Cardiology*, Tropical Medicine** and internal medicine*** Departments, Faculty of Medicine, \\ Zagazig University, Egypt.
}

\begin{abstract}
Background and aim: Interferon-based therapy is associated with significant side effects, including the cardiac complications; these may affect the patients' adherence to therapy and consequently the response rate. The aim of this study was to detect the types and predictors of interferon induced cardiac complications in the Egyptian hepatitis $\mathrm{C}$ virus infected patients treated with pegylated interferon/ribavirin combination therapy.

Patients and Methods: A total of 194, chronic HCV patients were followed up from the time of receiving treatment till 6 months after the end of treatment, to detect cardiac disorders and to determine the response status. Patients were assessed by through history taking, full clinical examination, full laboratory parameters and cardiac assessment using the standard 12 lead ECG and Transthoracic Doppler Echocardiography. Patients in the final analysis were divided into: Group A (who developed cardiac disorders) and group B (who did not develop cardiac disorders).

Results: The baseline clinical features (cardiovascular risk factors and hemodynamics) were comparable in both groups. Patients who developed cardiac disorders had higher baseline ALT level, hepatic fibrosis and histologic activity in the liver biopsy than patients without cardiac disorders $(\mathrm{P}<0.05)$. The confirmed cardiac complications represented $18 \%(\mathrm{n}=35)$ and included left ventricular systolic and diastolic dysfunction, pericardial effusion, arrhythmia and myocardial ischemia. Histological activity in the liver biopsy, ejection fraction (EF) and left ventricular end diastolic dimension (LVEDD) were independent predictors for cardiovascular complications.

Conclusion: Pegylated interferon therapy of chronic HCV is associated with many types of cardiac complications, predictors of which were histological activity in the liver biopsy, EF and LVEDD.
\end{abstract}

Key words: Pegylated Interferon; Hepatitis C virus; Cardiovascular complications of interferon.

\section{INTRODUCTION}

H epatitis $\mathrm{C}$ virus (HCV) infection is the most common cause of newly diagnosed chronic liver disease worldwide [1] and is the single most important cause of liver disease in Egypt [2,3], with the latest anti-HCV antibody prevalence of $14.7 \%$ [4]. Hence, it is very important that the disease be treated in its early stages, which will effectively reduce the morbidity and mortality associated with this disease [5]. The current recommended therapy for chronic $\mathrm{HCV}$ is the combination of pegylated interferon alpha (Peg-IFN- $\alpha$ ) and ribavirin (RBV) that was proven to be superior to the standard interferon alpha and ribavirin [6, 7]. Peg-IFN- $\alpha$ based therapy is known to be associated with significant side effects that may have an impact on tolerability, compliance, ability to maintain optimal dosing regimens, and ultimately the response to therapy if dose reductions or discontinuations are required [8].

Cardiovascular effects related to interferon-alpha have been reported in 5 to $15 \%$ of patients [9]. A wide range of cardiac complications has been reported, including dilated cardiomyopathy (which mostly occurs after a prolonged time of treatment), arrhythmias, and ischemic heart disease. Most cardiotoxic effects, including cardiomyopathy are reversible following cessation of IFN- $\alpha$ [10]. Other less common and less dangerous side effects detected in less than $5 \%$ of the patients in non-randomized studies are: lowlevel conduction impairment or reversible hypertension and the exact physiopathology of this cardiotoxicity remains unknown [11]. 
In Egypt; only few registries are available till now, despite the overwhelming increase in the number of people infected with hepatitis $\mathrm{C}$ virus and on treatment with interferon. The aim of this study was to detect the types and predictors of interferon induced cardiac complications in the Egyptian $\mathrm{HCV}$ infected patients treated with pegylated interferon/ribavirin combination therapy.

\section{SUBJECTS AND METHODS}

Study: Prospective observational.

Subjects: This study has been carried out on 194 Egyptian HCV cases attending HCV treatment clinics in Zagazig University Hospitals, Sharkiya Governorate, Egypt. Cases included were referred to the Cardiology outpatient clinic, Zagazig University Hospitals for further assessment. All patients were candidates for treatment by Peg-IFN- $\alpha$ and RBV according to the modified guidelines of the National Committee for Control and Prevention of viral Hepatitis "C" in Egypt [12]. Patients with chronic hepatitis B (HBV), HBV/HCV coinfection, cirrhotic patients, autoimmune hepatitis; cardiac disease (cardiomyopathy, arrhythmias, ischemia, myocarditis, and valvular disorders), renal impairment, thyroid dysfunction, and psychiatric disorders were excluded from the study. Habitual alcohol drinkers and drug abusers were also excluded.

Patients were classified in the final analysis into two groups: group A comprised 96 patients who developed cardiac disorders and group B comprised 98 patients who did not develop cardiac disorders. Approval was obtained for performing the study from the Institutional Review Board of the Faculty of Medicine, Zagazig University, Egypt.

After giving an informed consent, all patients were subjected to the following:

1- Baseline demographic data collection regarding age, sex and associated chronic diseases. Cardiac evaluation; general examination, chest X-ray, electrocardiography (ECG) and echocardiographic (Echo) studies.
2- Baseline laboratory data, including HCV RNA level, bilirubin, ALT, AST, serum creatinine level, blood glucose (fasting and two hours postprandial), complete blood count (CBC), TSH, ANA titer $<1: 20$ and liver biopsy (grading of activity and staging of fibrosis was evaluated by Ishak [13] classification which classifies hepatic activity by a score from 1 to 18 and hepatic fibrosis from 1 to 6 ).

3- Treatment regimens: The Peg-IFN alpha was given subcutaneously around the umbilicus once per week together with $\mathrm{RBV}$, using $1000 \mathrm{mg}$ /day for those $\leq 75$ $\mathrm{kg}$ in weight and $1200 \mathrm{mg} /$ day for those $>75 \mathrm{~kg}$ in weight.

4- Patient Monitoring: Patients were assessed at weeks $0,1,2$ and 4 of treatment and thereafter monthly and on the development of symptoms. At each visit the followings were done:

- Laboratory tests, including: serum ALT, AST, bilirubin, creatinine, CBC. TSH was measured at regular intervals during and after treatment. Body weight and symptom checklist were recorded at each visit.

- Assessment of the response status for the combination therapy, by qualitative PCR, at week 12 , week 24, week 48 and 6 months after the end of antiviral therapy to determine the sustained virological response (SVR).

- Cardiological assessment, including:

a- Symptoms analysis: including shortness of breathing (SOB), paroxysmal nocturnal dyspnea (PND), palpitation and chest pain.

b- Clinical examination, including blood pressure, pulse (for rate and rhythm), signs of heart failure (HF); neck veins for congestion, lower limbs for edema, fine bilateral basal crepitations or additional heart sounds (S3 or S4). 
c- Standard 12 lead ECG, to document the presence of significant ST- $\mathrm{T}$ wave changes suggestive of ischemia; (when the resting ECG reveals ST-segment depression greater than $0.1 \mathrm{mV}(1 \mathrm{~mm})$, deep $\mathrm{T}$ wave inversion and/or ST-segment elevation of $0.2 \mathrm{mV}(2 \mathrm{~mm})$ in chest leads and $0.1 \mathrm{mV}(1 \mathrm{~mm})$ in limb leads) [14] and rhythm or conduction disturbance.

d- Transthoracic Doppler Echocardiography (Echo):

Conventional echo, and Doppler studies were performed for all patients using a Hewlett Pakard (SONOS 5500) echo-set using a 2.5 $\mathrm{MHz}$ transducer. Echo, study was obtained at rest with the subjects in the left lateral decubitus position. Two-dimensional guided M-mode (2D Echo) measurements of the following: left ventricular end diastolic dimension (LVEDD), LV end Systolic dimension (LVESD) and ejection Fraction (EF) \%. Doppler study of the mitral valve flow measuring: the E-wave, A-wave and E/A ratio from the apical 4chamber view. Evaluation of the pericardium was also done.

\section{DEFINITIONS}

Abnormal Echocardiographic parameters $[15,16]$ :

- Dilated left ventricle: when LVEDD $>53 \mathrm{~mm}$ in women and $59 \mathrm{~mm}$ in men.

- Impaired LV systolic function: when $\mathrm{EF}<55 \%$.

- Impaired LV diastolic function: grade I when the mitral $\mathrm{E} / \mathrm{A}$ ratio $<1$, grade II (pesudonormal when E/A > 1) discovered by Valsalva or by tissue Doppler and grade III (restrictive pattern) when E/A $>2$.

Cardiological assessment was performed by the cardiologist author and another independent cardiologist, both have high experience in
ECHO studies to minimize the inter observer variability that may affect the readings.

Statistical Analysis: Data were collected and analyzed using SPSS (Statistical Package for the Social Sciences) version 15. Continuous variables were expressed as mean \pm SD and categorical variables are expressed as percentages. Comparison of variables between the two groups was performed by the $X^{2}$ test and student's t test. Multivariate linear logistic regression analysis was used to find out the significant independent predictor/s of cardiac complications in patients on interferon therapy. A value of $\mathrm{P}<0.05$ was considered statistically significant.

\section{Study participants}

\section{RESULTS}

This study included 194 chronic HCV patients, 111 (57.2\%) were males and 83 $(42.8 \%)$ were females, their ages ranged from 18 to 60 years. All patients were followed up from the time of initiation of the combined antiviral therapy for six months after the end of treatment to determine the SVR for responder patients or the time of discontinuation of therapy for non responder patients. There were no dropouts from the scheduled cardiovascular assessment visits; all patients completed the study and were compliant with the regular interviews including the non responders. No cessation of therapy due to cardiac complications except one patient, who died due to massive, rapidly accumulating pericardial effusion (aspiration showed hemorrhagic massive effusion, its analysis showed that it was bloody, with neither inflammatory, viral nor bacterial affection of the pericardium and it was associated with thrombocytopenia). Patients' baseline characteristics are shown in Table 1.

\section{Clinical, biochemical, virological and} pathological features:

The two groups were comparable in their baseline clinical features (cardiovascular risk factors, hemodynamics), baseline viral load (quantitative PCR), biochemical features and the response rate, except for ALT that was significantly higher $(50.94 \pm 27.547 \mathrm{IU} / \mathrm{L})$ in 
group A vs. (43.31 $\pm 22.916 \mathrm{IU} / \mathrm{L})$ in group B (p $<0.05)$. Patients in group $A$ had advanced hepatic fibrosis $(\mathrm{p}<0.05)$ and necroinflammatory activity $(p<0.001)$ in the liver biopsy when compared to patients in group B (Table 1).

\section{Cardiac disorders in group A:}

The reported Cardiac disorders (clinical, ECG and Echo) were in the form of: 13 patients developed SOB (3 with HF, 4 with palpitation and 3 with ST-T wave changes), 31 patients developed palpitation (17 with anemia and 3 with premature atrial contractions “PAC"), 15 patients developed chest pain (3 with typical ischemic chest pain and ST-T wave changes in ECG and 6 with stitching pain of pericarditis with development of effusion in Echo). Echo study showed: LVEDD >53/59 $\mathrm{mm}$ in 18 patients by the end of the course, with early cardiomyopathic changes $(\mathrm{EF}<55 \%)$ in 3 cases (dilated cardiomyopathy) and 5 patients developed LV diastolic dysfunction (Table 2).

The Actual Cardiovascular Complications: The actual rate of cardiovascular side effects in this study was $18 \%(n=35)$, of them 3 patients developed typical ischemic chest pain and ST-T wave changes in ECG with normal cardiac enzymes. Three cases showed premature atrial contractions (PAC). Echocardiographic parameters showed: marked left ventricular dilatation reported in 18 patients by the end of the course, with early myopathic changes and marked reduction in EF from base line in 3 cases (cardiomyopathy with development of HF, with FBBC, S3 gallop, lower limb edema and only one with congested pulsating neck veins, all of them improved with medical treatment within 6 months after the end of interferon course), 5 patients developed LV diastolic dysfunction (grade I in 3 patients and grade II in 2 patients), 6 cases developed pericardial effusion. We reported 1 case of death due to massive hemorrhagic pericardial effusion (Figure 1).

\section{Echocardiographic parameters:}

There was no statistically significant difference between group A and group B as regard the echocardiographic parameters (LVEDD, LVESD, E/A ratio and EF) at the baseline, while there was a statistically significant difference between group A and group B as regard LVEDD, LVESD and EF after the end of therapy.

There was no statistically significant difference in echocardiographic parameters before and after therapy in group B patients.

LVEDD was significantly increased in group A after the end of therapy $(48.9 \pm 2.44$ vs $52.9 \pm 3.58 \mathrm{~mm})(\mathrm{p}<0.05)$, also LVESD was significantly increased in group A after the end of therapy $(32.3 \pm 0.38$ vs $35.7 \pm 2.49 \mathrm{~mm})$ $(\mathrm{p}<0.05)$. These resulted in significant reduction in $\mathrm{EF}$ in group $\mathrm{A}$ from $(71.33 \pm 6.13 \%)$ at baseline to $(59.61 \pm 12.53 \%)$ after the end of therapy $(\mathrm{p}<0.05)$ (Table 3$)$.

Predictors of cardiovascular complications:

Logistic regression analysis of different parameters in patients with cardiovascular complications showed that the advanced degree of histological activity in the liver biopsy, the lesser EF and the more LVEDD were independent predictors for the occurrence of cardiovascular complications (Table 4). 
Table 1: Basal characteristics of both groups.

\begin{tabular}{|c|c|c|c|}
\hline & $\begin{array}{c}\text { Group A } \\
N=96\end{array}$ & $\begin{array}{c}\text { Group B } \\
N=98\end{array}$ & $\mathrm{P}$ \\
\hline Age (years) & $44.3 \pm 7.9$ & $43.6 \pm 6.4$ & NS \\
\hline Systolic BP (mmHg) & $127.2 \pm 14.009$ & $130.56 \pm 13.09$ & NS \\
\hline Diastolic BP $(\mathrm{mmHg})$ & $79.11 \pm 9$ & $80.61 \pm 9.63$ & NS \\
\hline Pulse rate(beat/minute) & $76.75 \pm 10.95$ & $74.4 \pm 11.24$ & NS \\
\hline $\begin{array}{c}\text { Female }(\%) \\
\text { Male }(\%) \\
\end{array}$ & $\begin{array}{l}47(49 \%) \\
49(51 \%) \\
\end{array}$ & $\begin{array}{l}36(36.7 \%) \\
62(63.3 \%) \\
\end{array}$ & NS \\
\hline BMI Mean \pm SD & $27.3 \pm 3.7$ & $27.2 \pm 2.9$ & NS \\
\hline $\begin{array}{l}\text { Negative } \\
\text { Active } \\
\text { X-smoker }\end{array}$ & $\begin{array}{l}60.3 \% \\
18.4 \% \\
21.1 \% \\
\end{array}$ & $\begin{array}{l}57.9 \% \\
31.6 \% \\
10.5 \% \\
\end{array}$ & NS \\
\hline$\overline{\text { HTN }(\%)}$ & $13(13.7 \%)$ & $11(11.2 \%)$ & NS \\
\hline $\mathbf{D M}(\%)$ & $15(15.6 \%)$ & $18(18.4 \%)$ & NS \\
\hline AST (IU/L) Mean \pm SD & $49.33 \pm 28.12$ & $49.38 \pm 28.24$ & NS \\
\hline ALT (IU/L) Mean \pm SD & $50.94 \pm 27.547$ & $43.31 \pm 22.916$ & $<0.05$ \\
\hline Hb $(\mathrm{gm} / \mathrm{dl})$ Mean \pm SD & $14.1 \pm 1.907$ & $14.49 \pm 1.35$ & NS \\
\hline PLT $\left(10^{9} / \mathbf{L}\right)$ Mean \pm SD & $186.7 \pm 58.3$ & $185.3 \pm 54.1$ & NS \\
\hline $\begin{array}{r}\text { Liver Biopsy (Ishak): } \\
\text { Activity } \\
\text { Fibrosis }\end{array}$ & $\begin{array}{l}6.95 \pm 3.26 \\
2.47 \pm 1.43 \\
\end{array}$ & $\begin{array}{c}5.67 \pm 1.803 \\
2.09 \pm 1.29\end{array}$ & $\begin{array}{l}<0.001 \\
<0.05\end{array}$ \\
\hline Basal HCV RNA PCR $\left.(\mathrm{IU} / \mathrm{mL}) \mathrm{X} 10^{5}\right) \quad$ Mean \pm SD & $3.3 \pm 8.6$ & $2.2 \pm 3.8$ & NS \\
\hline Response Rate $(\%)$ & $54(55.1 \%)$ & $61(63.5 \%)$ & $\mathrm{NS}$ \\
\hline
\end{tabular}

HTN: hypertension, DM: diabetes mellitus, SBP: systolic blood pressure, DBP: diastolic blood pressure, HR: heart rate, bpm: beat per minute, BMI: body mass Index, Hb: hemoglobin, PLT: platelets. PCR: Basal HCV RNA, NS: non-significant.

Table 2: Cardiac disorders in group A.

\begin{tabular}{cc}
\hline & $\begin{array}{c}\text { Group A } \\
\mathbf{N = 9 6}\end{array}$ \\
\hline Shortness of breath & $13(13.5 \%)$ \\
\hline Palpitations & $31(32.3 \%)$ \\
\hline Chest pain & $15(15.6 \%)$ \\
\hline HF $-\mathrm{T}$ wave changes & $3(3.1 \%)$ \\
\hline Arrhythmias(PAC) & $3(3.1 \%)$ \\
\hline LV systolic disturbances: & $3(3.1 \%)$ \\
- LVEDD (increase by $>$ 5mm from base line) & \\
- LVEDD $>53 / 59 \mathrm{~mm}$ & $25(26 \%)$ \\
- EF (decrease by $>5 \%$ from baseline) & $18(19 \%)$ \\
- EF<55\% & $21(22 \%)$ \\
\hline LV diastolic dysfunction & $3(3.1 \%)$ \\
\hline Pericardial effusion & $5(5.2 \%)$ \\
\hline
\end{tabular}

HF: heart failure, PAC: premature atrial contractions, LV: left ventricular, LVEDD: left ventricular end diastolic dimension, EF: ejection Fraction. 
Table 3: Echocardiographic parameters, in both groups before and after treatment.

\begin{tabular}{|c|c|c|c|}
\hline & $\begin{array}{c}\text { Group A } \\
\mathrm{N}=96 \\
\end{array}$ & $\begin{array}{c}\text { Group B } \\
\mathrm{N}=98 \\
\end{array}$ & $\mathrm{P}$ \\
\hline $\begin{array}{c}\text { LVEDD }(\mathbf{m m}) \\
\text { before } \\
\text { treatment }\end{array}$ & $48.9 \pm 2.44$ & $48.3 \pm 0.50$ & NS \\
\hline $\begin{array}{c}\text { LVEDD }(\mathbf{m m}) \\
\text { after } \\
\text { treatment }\end{array}$ & $52.9 \pm 3.58$ & $48.1 \pm 0.48$ & $<0.05$ \\
\hline $\begin{array}{c}\text { LVESD }(\mathbf{m m}) \\
\text { before } \\
\text { treatment }\end{array}$ & $32.3 \pm 0.38$ & $31.3 \pm 2.15$ & NS \\
\hline $\begin{array}{c}\text { LVESD(mm) } \\
\text { after } \\
\text { treatment }\end{array}$ & $35.7 \pm 2.49$ & $30.8 \pm 0.415$ & $<0.05$ \\
\hline $\begin{array}{c}\text { EF }(\%) \text { before } \\
\text { treatment }\end{array}$ & $71.33 \pm 6.13$ & $70.85 \pm 5.32$ & NS \\
\hline $\begin{array}{c}\mathrm{EF}(\%) \text { after } \\
\text { treatment }\end{array}$ & $59.61 \pm 12.53$ & $71.93 \pm 6.05$ & $<0.05$ \\
\hline $\begin{array}{c}\text { E/A before } \\
\text { treatment }\end{array}$ & $1.15 \pm 0.281$ & $1.22 \pm 0.282$ & NS \\
\hline $\begin{array}{l}\text { E/A after } \\
\text { treatment }\end{array}$ & $1.16 \pm 0.278$ & $1.2 \pm 0.251$ & NS \\
\hline
\end{tabular}

LVESD: LV end Systolic dimension, E: peak early diastolic mitral flow, A: peak late diastolic mitral flow, NS: non-significant. Differences in the parameters before and after IFN- $\alpha$ therapy were assessed by the paired t-test.

Table 4: Logistic regression analysis, of the different parameters, in patients with cardiovascular complications.

\begin{tabular}{llll}
\hline Variable & B & Wald & Sig. \\
\hline Age & -0.014 & 0.417 & NS \\
\hline Sex & -0.639 & 3.317 & $\mathrm{NS}$ \\
\hline ALT & .006 & .336 & $\mathrm{NS}$ \\
\hline PCR & 0.000 & 0.409 & $\mathrm{NS}$ \\
\hline Histological activity & .467 & 6.492 & $<0.05$ \\
\hline Hepatic fibrosis & -.252 & .626 & $\mathrm{NS}$ \\
\hline LVEDD & 3.189 & 18.016 & $<0.001$ \\
\hline LVESD & -1.401 & 3.404 & $\mathrm{NS}$ \\
\hline Ejection fraction & -.165 & 11.462 & $<0.001$ \\
\hline
\end{tabular}

PCR: Basal HCV RNA, LVEDD: left ventricular end diastolic dimension, LVESD: left ventricular end Systolic dimension, EF: ejection Fraction. 


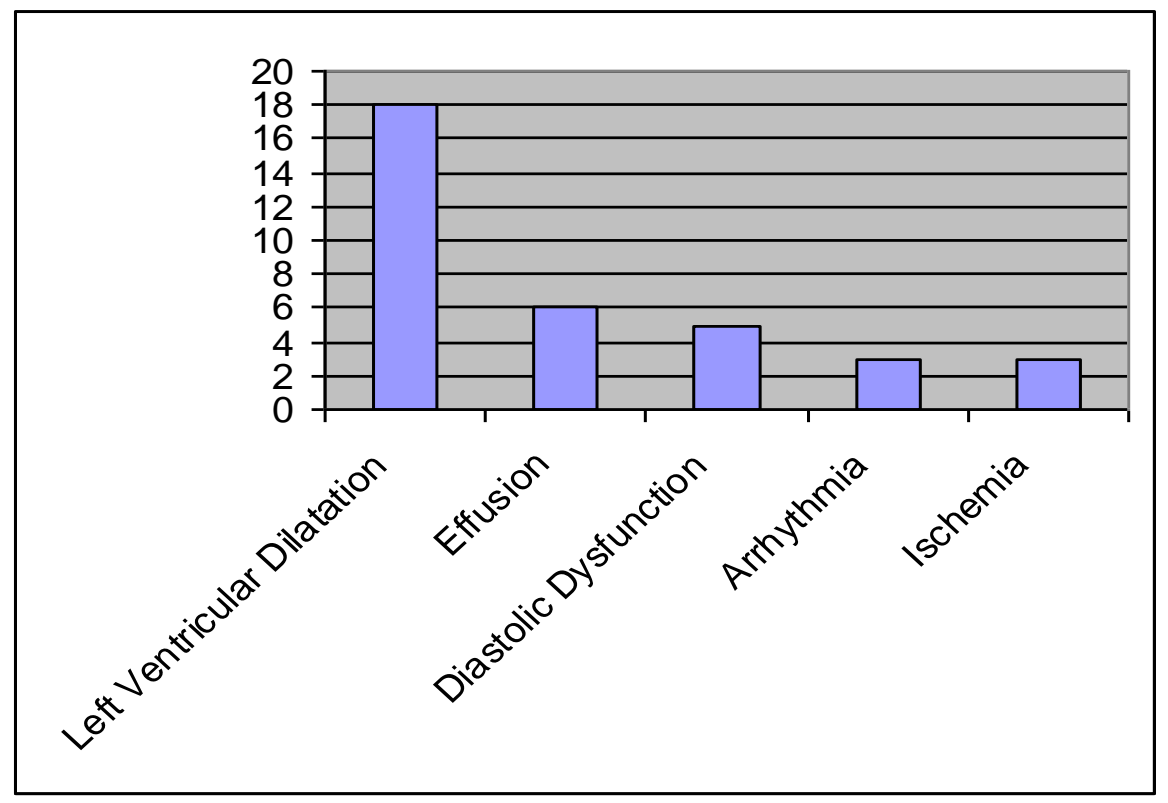

Figure 1: The reported cardiovascular complications.

\section{DISCUSSION}

Chronic $\mathrm{HCV}$ is being increasingly treated, and infectious disease physicians as well as young gastroenterologists are more and more incorporated in the management with interferon based therapies. Many of them are not familiar with the serious cardiovascular complications of interferon, especially in Egypt, where a nationwide HCV treatment program under surveillance of the Ministry of Health and the Health insurance conduced years ago. Consequently, many patients are treated, and the chance to develop these complications increases.

This study found that interferon based therapy is associated with various cardiovascular complications and some of them end with case fatalities, a serious concern that should raise not only physicians' but also patients' awareness about these adverse events and importance of adherence with the scheduled regular interviews.

The rate of cardiovascular complications in this study was $18 \%$, a rate higher than the rate reported in the international $[9,11]$ as well as the Egyptian literature [17]. In fact, an interesting study from Egypt by Almawardy $\mathrm{R}$ et al., [17], assessed the myocardial toxicity of interferon in a 120 chronic HCV patients at baseline and 6 months after initiation of the combination therapy, they excluded non responders and there was a dropout of 45 patients and they reported rates of myocardial toxicity lower than the rates we reported. This can be explained by many reasons. Firstly, the aim of our study was to report all cardiovascular side effects including the asymptomatic Echo changes and not only to assess myocardial function. Secondly, the large number of patients in our cohort compared to the smaller number of patients in many other studies. Thirdly, the duration of follow up: 6 months after end of treatment in our study. This enabled us to pick up delayed cardiovascular complications of interferon even after cessation of treatment. Fourthly, cardiovascular follow up visits (multiple cardiac assessment visits). Fifthly, the rate of dropouts (the cardiovascular assessment interviews): none in our study. Furthermore, we did not exclude the nonresponder patients who still at risk of developing cardiovascular complications due to 
the cumulative effect of Peg-IFN- $\alpha$ /RBV irrespective of their response status.

Left ventricular dilatation and consequently reduction in $\mathrm{EF}$ were the most common cardiovascular complications reported in this study to the degree of cardiomyopathy in 3 cases. There are multiple mechanisms by which a potent activator of the immune system such as IFN could induce myocardial dysfunction and cardiomyopathy, including new or enhanced immunoglobulin production as detected by the presence of specific antibodies against myocytes in the blood of the affected patients [18] and enhanced cell mediated immunity as detected in the biopsy and autopsy [19].

Higher rates of $\mathrm{HCV}$ induced myocarditis and cardiomyopathies were reported from the Japanese literature [20]. It was also reported from the West and even resolution of heart failure and myocardial injury was reported in $\mathrm{HCV}$ patient after complete eradication [21]. These data need further confirmation in Egyptian patients and should be studied in relation to HCV genotype.

Myocardial ischemia reported in this study was not progressed to myocardial infarction, meanwhile the risk to develop this potentially fatal complication is present due to many factors associated with IFN therapy, including anemia that commonly complicate patient management both due IFN induced bone marrow suppression and RBV induced hemolytic anemia. Ischemic events may also result from the property of IFN-alpha to increase the thickness of capillary walls leading to narrowing of the luminal size as was shown in an animal model [22]. The presence of antiINF antibody in the absence of pathologic alterations on coronary angiography, suggest that the coronary spasms were the result of an immune mechanism [22, 23]. INF has also been shown to influence the cytokine network and autonomic nervous system functions which may result in coronary vasospasm [24]. In addition, IFN- alpha has been demonstrated to yield an unfavorable lipid profile consisting of an increase in triglycerides and very low density lipoprotein (VLDL) cholesterol while high density lipoprotein (HDL) cholesterol decreased [25].

The types of arrhythmias reported in this study were of atrial origin. Interferon induced arrhythmia is not a novel finding of this study, where a 58-year old Egyptian female reported ventricular extra-systoles on top of sinus tachycardia with syncopal attacks and was overcome by IFN dose reduction [30].

Interferon may have induced local inflammation in the conduction system in response to an immune reaction, resulting in variable types of arrhythmia (ventricular or supra-ventricular) [26]. It may induce ventricular late potentials and related arrhythmias in patients with chronic active hepatitis due to the reversible electrophysiological effects of IFN [27], or cause sympathetic nervous system activation [28]. Another study suggested that the arrhythmogenic effect of the standard INF may be mediated by decreases in heart rate variability indices [29].

IFN- $\alpha$ is known to induce expression of various chemokines [31], that results in increased pericardial inflammation and fibrosis, leading to pericarditis and also myocarditis [32]. We reported 6 cases with pericardial effusion; one case developed tamponade and died.

In this study the occurrence of cardiovascular troubles was higher in patients with higher baseline ALT, hepatic fibrosis and hepatic histological activity. We have no data from the available literature about this association, but advanced hepatic affection reflected by these parameters may point to cardiac affection as well, added to the cardiotoxic effect of IFN and this may be another explanation for the high rate of complications reported in this study.

In conclusion, cardiovascular complications in Egyptian chronic $\mathrm{HCV}$ patients treated with pegylated IFN alpha are not infrequent. Patients with high baseline ALT, hepatic fibrosis and histologic activity are prone to develop these complications. So 
rigorous cardiological monitoring of all patients receiving this treatment seems necessary.

Larger studies using more investigation modalities for detection of myocardial injury and further follow up of the complicated cases are recommended for longer time.

Acknowledgment: To Dr. Layla M El Maghawry, following her guidance we soundly conducted this study in its present form. We also would thank all staffs who share in the arrangement and delivery of the services to the patients.

\section{REFRANCES}

1. Lavanchy D. Evolving epidemiology of hepatitis C virus. Clin Microbiol Infect. 2011;17(2):107-15.

2. El-Zayadi AR, Selim O, Ibrahim EH, Hamdy H, Dabbous H, Ahdy A, et al. Does schistosomiasis play a role in the high sero prevalence of $\mathrm{HCV}$ antibody among Egyptians? Trop Gastroenterol 1997; 18: 98-100.

3. Habib M, Mohamed MK, Abdel-Aziz F, Magder LS, Abdel-Hamid M, Gamil F et al. Hepatitis C virus infection in a community in the Nile Delta: risk factors for seropositivity. Hepatology 2001; 33: 248-53.

4. El-Zanaty F, Way A. Egypt Demographic and Health Survey 2008. Egyptian: Ministry of Health (El-Zanaty and Associates and Macro International, Cairo). 2009: 431.

5. European Association for Study of Liver. EASL Clinical Practice Guidelines: management of hepatitis C virus infection. J Hepatol. 2014 Feb; 60(2):392-420.

6. Manns M, McHutchison J, Gordon S, Rustgi VK, Shiffman M, Reindollar R et al. Peg interferon alfa- $2 \mathrm{~b}$ plus ribavirin compared with interferon alfa-2b plus ribavirin for initial treatment of chronic hepatitis $\mathrm{C}$ : a randomized trial. Lancet 2001; 358: 958-65.

7. Ghany MG, Strader DB,Thomas DL, Seeff LB; American Association for the Study of Liver Diseases. AASLD PRACTICE GUIDELINES: Diagnosis, Management, and Treatment of Hepatitis C: An Update. Hepatology 2009; 4 (4):1335-74.

8. Al-Zahrani H, Gupta V, Minden MD, Messner HA, Lipton JH. Vascular events associated with alpha interferon therapy. Leuk Lymphoma 2003; 44(3):471-5.

9. Interferon alfa In: McEvoy GK, Pharmacists
ASoH-S, editors. Ahfs Drug Information, 1996 Bethesda, Maryland: American Society of Health-System Pharmacists; 1996.

10. Sonnenblick M, Rosin A. Cardiotoxicity of interferon. A review of 44 cases. Chest 1991; 99(3): 557-61.

11. Le Corguillé M1, Pochmalicki G, Eugène C. Cardiovascular complications of alpha interferon. Gastroenterol Clin Biol. 2007;31(12):1081-4.

12. Emara MH, El-Gammal NE, Mohamed LA, Bahgat MM. Occult hepatitis B infection in Egyptian chronic hepatitis $\mathrm{C}$ patients: prevalence, impact on pegylated interferon/ribavirin therapy. Virol J. 2010; 7:324.

13. Ishak K, Baptista A, Bianchi L, Callea F, De Groote J, Gudat F, et al. Histologic grading and staging of chronic hepatitis. J Hepatol 1995;24:289-293.

14. Wagner GS, Macfarlane $\mathrm{P}$, Wellens $\mathrm{H}$, Josephson M, Gorgels A, Mirvis DM, et al: AHA/ACCF/HRS Recommendations for the Standardization and Interpretation of the Electrocardiogram. Part VI: Acute Ischemia/Infarction: A Scientific Statement from the American Heart Association Electrocardiography and Arrhythmias Committee, Council on Clinical Cardiology; the American College of Cardiology Foundation; and the Heart Rhythm Society: Endorsed by the International Society for Computerized Electrocardiology. Circulation 2009; 119: e262e270.

15. Lang RM, Bierig $M$, Devereux $R \quad B$, Flachskampf FA, Foster E, Pellikka PA, et al: Recommendations for chamber quantification: a report from the American Society of Echocardiography's Guidelines and Standards Committee and the Chamber Quantification Writing Group, developed in conjunction with the European Association of Echocardiography, a branch of the European Society of Cardiology. J Am Soc Echocardiogr2005 Dec; 18(12):144063.

16. Nagueh SF, Appleton CP, Gillebert TC, Marino $\mathrm{PN}, \quad \mathrm{Oh} \mathrm{JK}, \quad$ Smiseth OA, et al: Recommendations, for the evaluation of left ventricular diastolic function, by echocardiography. J Am Soc Echocardiogr2009 Feb; 22(2):107-33.

17. Almawardy R, Elhammady W, Mousa N, Abotaleb $\mathrm{S}$. Is Combination Therapy for 
Chronic Hepatitis C Toxic for Cardiac Function? Hepatitis Monthly 2012;12(8): 144-9.

18. Sacchi S, Kantarjian H, O'Brien S, Cohen PR, Pierce S, Talpaz M. Immune-mediated and unusual complications during interferon alfa therapy in chronic myelogenous leukemia. J Clin Oncol 1995;13: 2401-7.

19. Brassard DL, Grace MJ, Bordens RW. Interferon-alpha as an immunotherapeutic protein. J Leukoc Biol 2002; 71: 565-81.

20. Matsumori A. Role of hepatitis $C$ virus in cardiomyopathy. Ernst Schering Res Found Workshop. 2006;(55):99-120.

21. Sanchez MJ, Bergasa NV. Hepatitis C associated cardiomyopathy: Potential pathogenic mechanisms and clinical implications. Med Sci Monit 2008; 14(5): RA55-63.

22. Salman H, Bergman M, Bessler H, Alexandrova $\mathrm{S}$, Djaldetti M. The effect of interferon on mouse myocardial capillaries: an ultrastructural study. Cancer1999; 85(6):1375-9.

23. Zbinden G. Effects of recombinant human alpha interferon in arodent cardiotoxicity model. Toxicol Lett1990; 50:25-35.

24. Takahashi H ,Nishimura M, Sakamoto M, Ikegaki I, Nakanishi T, Yoshimura M. Effects of interleukin -1 b on blood pressure, sympathetic nerve activity, and pituitary endocrine functions in anesthized rates. Am J Hypertens 1992; 5:2249.

25. Fernandez-Miranda C, Castellano G, Guijarro C, Fernández I, Schöebel N, Larumbe S, et al. Lipoprotein changes in patients with chronic hepatitis $\mathrm{C}$ treated with interferon-alpha. Am J Gastroenterol 1998 Oct; 93(10):1901-4.

26. EL-Atrebi K, El-Bassyouni HT. Management of rare side effects of peginterferon and ribavirin therapy during hepatitis $\mathrm{C}$ treatment: a case report .Cases Journal 2009; 2:7429.

27. Mansat Krzyzanowska E,Dreno B, Chiffoleau A, Litoux P. Cardiovascular manifestations associated with interferon alpha $-2 \mathrm{~A}$.Ann Med Interne 1991; 142:576-81.

28. Odashiro K, Hiramatsu S, Yanagi N, Arita T, Maruyama T, Kaji Y, et al. Arrhythmogenic and inotropic effects of interferon investigated in perfused and in vivo rat hearts: influences of cardiac hypertrophy and isoproterenol. Circulation J 2002; 66: 1161-7.

29. Yamamoto T, Tsuchihashi T, Hayashi J, Kashiwagi S. Effect of interferon therapy on heart rate and sympathetic nervous system. Fukuoka Igaku Zasshi 1998 Jul; 89(7):207-15.

30. Takase B, Hamabe A, Uehata A, Hujioka T, Kondo T, Matsui $\mathrm{T}$, et al. Recombinant interferon alpha treatment decreases heart rate variability indices and impairs exercise tolerance in patients with chronic hepatitis. Biomed Pharmacother. 2005 Oct; 59(1):S163-8.

31. Parlato S, Santini SM, Lapenta C, Di Pucchio T, Logozzi M, Spada M, et al. Expression of CCR7, MIP-3beta, and Th-1 chemokines in type I IFN-induced monocyte-derived dendritic cells: importance for the rapid acquisition of potent migratory and functional activities. Blood 2001; 98:3022-9.

32. Afanasyeva M, Georgakopoulos D, Fairweather D, Caturegli P, Kass DA, Rose NR. Novel Model of Constrictive Pericarditis Associated with Autoimmune Heart Disease in Interferon gamma Knockout Mice. Circulation 2004; 110:2910-7. 
أنواع وعوامل التنبؤ بالمضاعفات القلبية للعلاج بالاتترفيرون و الريبافيرين فى المرضى المصريين المصابين بفيروس سى المزمن

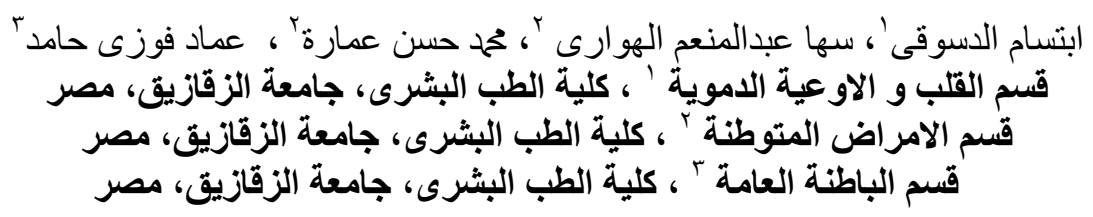

الخلفية العلمية و هدف البحث:

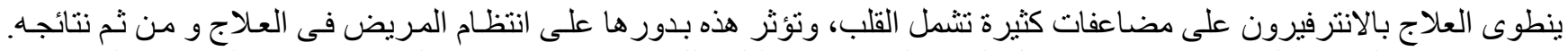

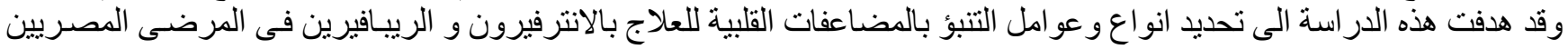
المصابين بفيروس سى المزهن.

المرضى و طرق البحث:

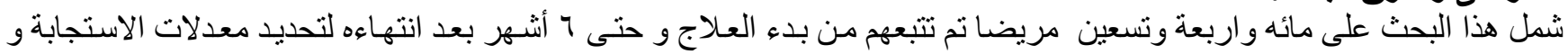

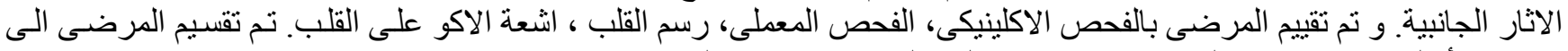

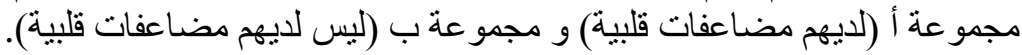

النتائج::

تشابهت المجمو عتان فى الصفات الاكلينيكة، مرضى المجمو عة (أ ) كان لايهه مستويات اعلى من انزيم الكبد، درجة التليف و النشـاط

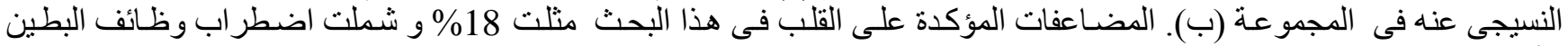

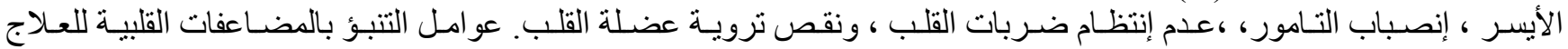

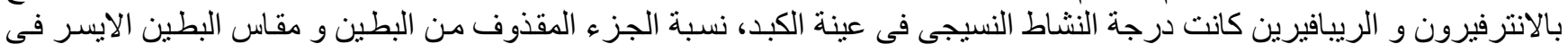
نهاية دورة الانبساط.

الخلاصة

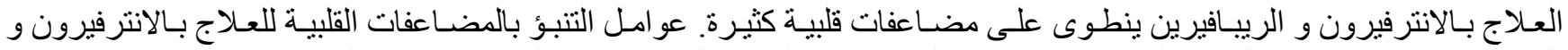

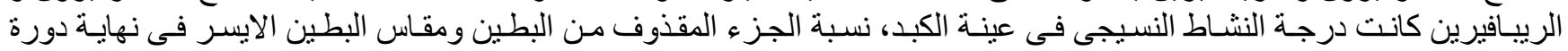

